Article

\title{
New Data Center Performance Index: Perfect Design Data Center-PDD
}

\author{
Alexandre F. Santos ${ }^{1,2,3}$, Pedro D. Gaspar $1,3, * \mathbb{C}$ and Heraldo J. L. de Souza ${ }^{2}$ \\ 1 Department of Electromechanical Engineering, University of Beira Interior, Rua Marquês d'Ávila e Bolama, \\ 6201-001 Covilhã, Portugal; d1682@ubi.pt \\ 2 FAPRO_Faculdade Profissional, Curitiba 80230-040, Brazil; heraldo@escolaprofissional.com \\ 3 C-MAST-Centre for Mechanical and Aerospace Science and Technologies, 6201-001 Covilhã, Portugal \\ * Correspondence: dinis@ubi.pt; Tel.: +351-275-329-759 (ext. 3759)
}

Received: 28 July 2020; Accepted: 23 September 2020; Published: 4 October 2020

check for updates

\begin{abstract}
Data Centers (DC) are specific buildings that require large infrastructures to store all the information needed by companies. All data transmitted over the network is stored on CDs. By the end of 2020, Data Centers will grow 53\% worldwide. There are methodologies that measure the efficiency of energy consumption. The most used metric is the Power Usage Effectiveness (PUE) index, but it does not fully reflect efficiency. Three DC's located at the cities of Curitiba, Londrina and Iguaçu Falls (Brazil) with close PUE values, are evaluated in this article using the Energy Usage Effectiveness Design (EUED) index as an alternative to the current method. EUED uses energy as a comparative element in the design phase. Infrastructure consumption is the sum of energy with Heating, Ventilating and Air conditioning (HVAC) equipment, equipment, lighting and others. The EUED values obtained were $1.245(\mathrm{kWh} / \mathrm{yr}) /(\mathrm{kWh} / \mathrm{yr}), 1.313(\mathrm{kWh} / \mathrm{yr}) /(\mathrm{kWh} / \mathrm{yr})$ and $1.316(\mathrm{kWh} / \mathrm{yr}) /(\mathrm{kWh} / \mathrm{yr})$ to Curitiba, Londrina and Iguaçu Falls, respectively. The difference between the EUED and the PUE Constant External Air Temperature (COA) is $16.87 \%$ for Curitiba, $13.33 \%$ for Londrina and $13.30 \%$ for Iguaçu Falls. The new Perfect Design Data center (PDD) index prioritizes efficiency in increasing order is an easy index to interpret. It is a redefinition of EUED, given by a linear equation, which provides an approximate result and uses a classification table. It is a decision support index for the location of a Data Center in the project phase.
\end{abstract}

Keywords: Data Center; PDD; PUE; cooling; EUED; performance index

\section{Introduction}

A data center (DC) is a processing infrastructure where computer systems of companies and/or organizations are gathered. It is an environment that has a large infrastructure where digital systems can communicate over a network, storing all the information needed by companies. All data transmitted are stored in the networks or generated in DC's. Thus, there is a physical infrastructure behind every solution used in computer systems. With the volume of use, storage, and technological evolution of the systems, platforms and services that are offered using networks, the available cloud computing services have increased. Therefore, the number of servers has increased so that the systems can carry out their proper operation and users obtain responses to their requests in a timely manner [1]. Continuous growth occurs, with the companies' revenues growing on average $24 \%$ per year and their investments more than 38\%; most of it is used for the construction and equipment of DCs [2]. As shown in Figure 1, $40 \%$ of the world's DC are located in the United States of America (USA). The highest growth rates have occurred in Europe and the Asia-Pacific. China, Japan, United Kingdom, Germany and Australia now account for $32 \%$ of the total [2]. 


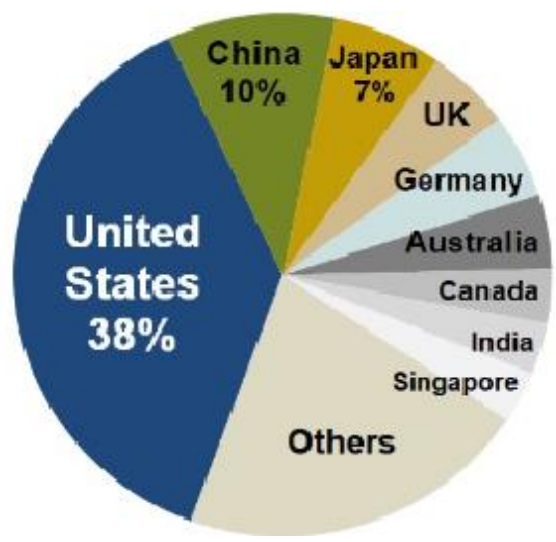

Figure 1. Location of data centers (DCs) by country [2].

With the increasing number of DCs installed in recent years, energy consumption has significantly increased. In the USA, DCs used 91 TWh, with an increase of 53\% in consumption (139 TWh) expected in 2020. The industry of information and communication technology (ICT) equipment continues to increase the equipment's data storage capacity and simultaneously its computational efficiency. In support of the DC operation, several sectors, including information technology (IT) industries, providers of physical infrastructure projects, DC layout projects and operators are focused on reducing the consumption of the DC's indirect energy, that is, of all the non-computational infrastructure, specifically energy and cooling systems [3]. To measure the energy efficiency of this large machinery, a consortium of companies known as The Green Grid has developed and recommended best practices for energy efficiency and sustainability, such as $\mathrm{CO}_{2}$ emissions. The metric created is an index known as Power Usage Effectiveness (PUE). The calculation is simple and is based on the relationship between the electrical energy consumed by the entire installation and the electrical energy consumed by the IT infrastructure equipment. The closer to 1.0 this index is, the better it is, that is the higher the energy efficiency is [4].

Other factors do not affect this index value, such as energy availability or seismic risk, with an exclusive focus on the area of greatest impact in addition to the IT equipment itself, which is the thermal area. A typical DC with PUE $=2.1$ has the distribution of electricity consumption shown in Figure $2[5]$.

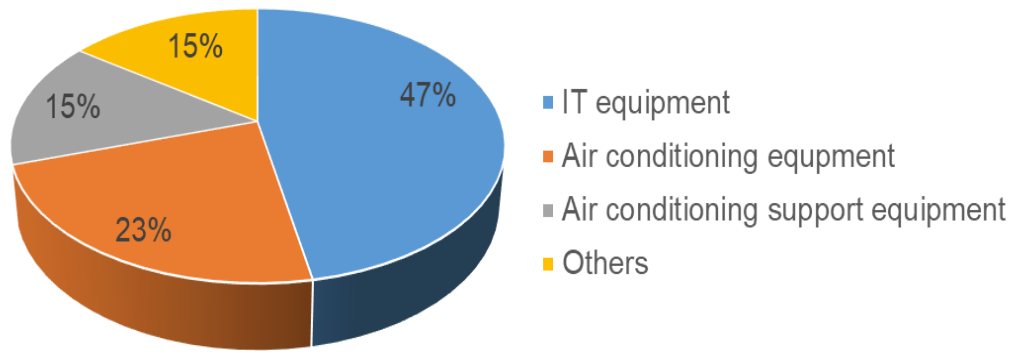

Figure 2. Distribution of electricity consumption in a typical DC with a Power Usage Effectiveness $(\mathrm{PUE})=2.1[5]$

The global DC electricity demand in 2018 was estimated at 198 TWh or almost $1 \%$ of the final global demand for electricity [6]. As shown in Figure 3, based on current trends in the efficiency of the hardware infrastructure, by 2021 the global energy demand of the DC is expected to decrease slightly to 191 TWh [6-9], despite the predicted $80 \%$ increase in DC traffic and 50\% in DC workloads over the next three years [9]. 


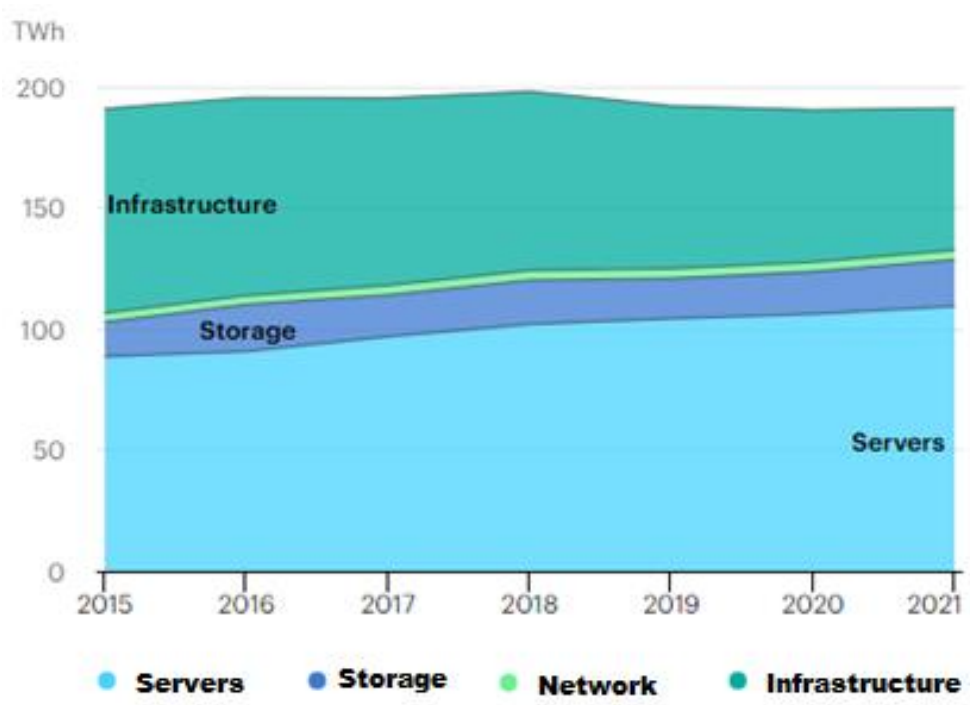

Figure 3. Global demand for electricity in DCs [9].

Shehabi et al. [8] estimated the historical DC electricity consumption by 2020, based on previous studies and historical shipping data. The consumption prediction was based on new trends and the most recent data available. Figure 4 provides an estimate of the total USA DC electricity usage (servers, storage, network equipment and infrastructure) from 2000 to 2020. In 2014, DCs in the USA consumed around 70 billion $\mathrm{kWh}$, representing about $1.8 \%$ of total US electricity consumption. The results of that study show that electricity consumption in the DCs increased by $4 \%$ between 2010 and 2014, a major change from the $24 \%$ increase estimated in 2005-2010 and the almost $90 \%$ increase estimated between 2000 and 2005. It is expected that energy use will continue to increase slightly in the near future, increasing by $4 \%$ from 2014 to 2020, the same rate as in the last five years. Based on current trend estimates, DC in the USA are expected to consume approximately 73 billion $\mathrm{kWh}$ in 2020.

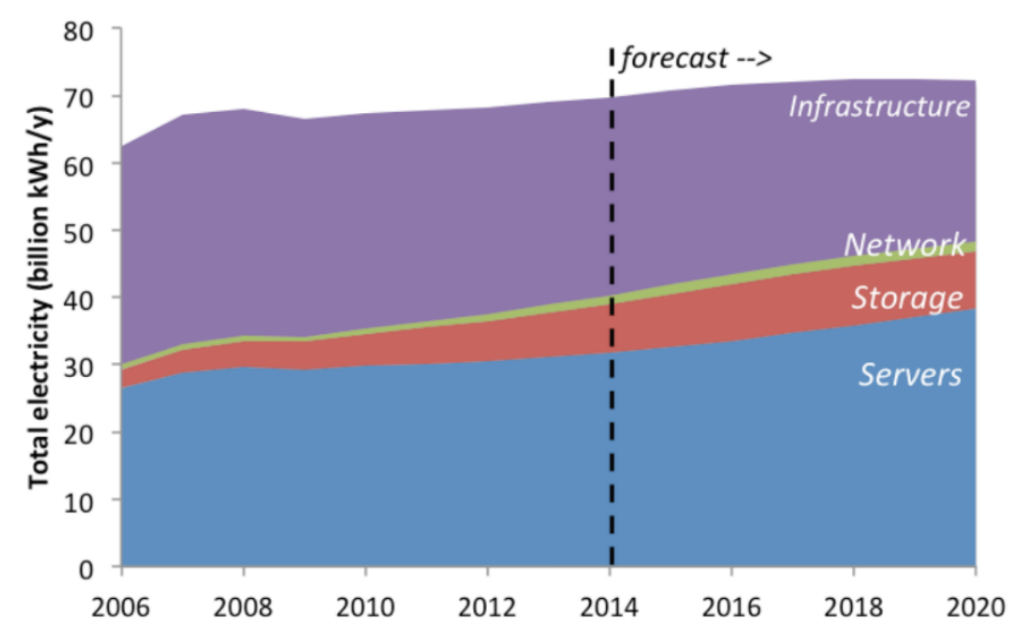

Figure 4. Total US DC electricity usage by technology type [9].

Today, PUE is the most used metric, which works with an emphasis on power and not on energy. In the design phase, the PUE uses concepts such as energies and others such as powers, both are correct, since in the design phase without simulation the metric uses a ratio between powers. In the application phase, that is with the project already executed and in operation, the PUE will be a mathematical ratio between energies. In recent years, a metric that will compare in the same type of air conditioning system, called Energy Usage Effectiveness Design (EUED) [10,11] has been studied. The EUED index uses the climatic data of $8760 \mathrm{~h}$ per year, using the wet and dry bulb data of those $8760 \mathrm{~h}$. The method 
stipulates psychrometric conditions for the use of free cooling, evaporative systems, and variable coefficients of performance (COPs). Applying the method with the data from the American Society of Heating, Refrigeration and Air Conditioning (ASHRA)E Weather Data Viewer, it is possible to know which annual hours each air conditioning solution applies in a specific region to install a DC. The EUED allows a simulation in the design phase that would only be possible in the field with the data center already installed. Just as the Integrated Part Load Value ((IPLV), Air-conditioning, Heating and Refrigeration Institute (AHRI) Standards 550/590-2015) metric was a revolution for air conditioning, the same idea of EUED being an evolution for the simulation of where to install a DC [12]. That index is used together with a new DC performance index, PDD (Perfect Design Data center). Both the EUED and the PDD indexes will be calculated for three different cities in the southern region of Brazil, with a similar PUE value. In addition to PUE, defined by The Green Grid, the Thermal Guidelines for Data Processing Environments [4] already has some simulations for the use of "Free Cooling" for some cities. In this study adiabatic evaporative systems are included in the simulations to compare EUED and PDD in relation to PUE. This work includes data analysis of:

- ASHRAE Thermal Guidelines for Processing [13] ( with the data for three cities);

- Geothermal temperature: from the cities Curitiba, Londrina, and Iguaçu Falls $[10,11]$.

For the calculation of EUED, PDD and for the subsequent comparison with the values of PUE constant external air temperature (COA), the analysis and discussion of results aims to obtain a higher level of information for the decision making of where to place a DC. Specifically, the PUE measures the relationship between the total energy consumed by the installation and energy consumed by the IT equipment [3] and the COA nomenclature means constant external air temperature using the average of the hottest $35.1 \mathrm{~h}$ of the year $(0.4 \%)$ as a design value, given by the ASHRAE Standard. This index in the design phase simulates the equipment in the worst condition in the region, while the performance of the equipment in the AHRI 1361 [14] condition simulates all equipment in a unique condition of $35^{\circ} \mathrm{C}$. This is the reason to emphasize the COP of the equipment with the air intake in the condenser at $35^{\circ} \mathrm{C}$ [14]. Note that a percentage comparison between the PUE COA and the EUED is interesting, since the EUED uses the wet and dry bulb temperatures of $8760 \mathrm{~h}$ of data given by the ASHRAE Weather Data Viewer [15], while the PUE is based on Association Brazilian Standards Techniques (ABNT) Brazilian Standards (NBR) 16401 [16].

The EUED is an index that instead of observing only one point with reference to the PUE (emphasis on air conditioning machines), provides a more comprehensive and global view of the whole, as it places emphasis on the environment as a whole. This analysis involves all the natural parameters of the regions that will be addressed in the course of deciding the location where to set the DC. The EUED given by Equation (1) is used in the design phase to predict a measure of the DC efficiency. The PDD (Perfect Design Data center) is an index that prioritizes efficiency in an increasing order, and is an index easy to interpret. In reality, PDD is a redefinition of EUED.

$$
\text { EUED }=\frac{\text { Total DC Energy with entalpic variations }[\mathrm{kWh} / \mathrm{yr}]}{\text { Specific consumed Energy IT equipment }[\mathrm{kWh} / \mathrm{yr}]}
$$

\section{Chosen Cities and Characteristics}

The calculation of these new indexes is based on a high-density DC that can be placed in the cities of Curitiba, Londrina and Iguaçu Falls located in the state of Paraná, Brazil, that have similar characteristics. The cities are close to large hydrographic basins and based only on Brazilian Association of Technical Standards (ABNT), using the annual frequency, wet bulb temperature (WBT), dry bulb temperature (DBT) and altitude [15]. The difference between the dry bulb temperatures, DBT, $(0.4 \%$ average of the hottest hours of the year-Freq. year (\%)) of the cities Curitiba and Londrina is $46.1 \%$ and that of Curitiba and Iguaçu Falls is $51.3 \%$, and for psychrometric effects of the altitude between the cities is Curitiba 908 m, Londrina 570 m and Iguaçu Falls 243 m, as shown in Table 1. 
Table 1. Climate data of cities of Curitiba, Londrina and Iguaçu Falls (Brazil) [16].

\begin{tabular}{|c|c|c|c|c|}
\hline Cities & Freq. Year [\%] & WBT $\left[{ }^{\circ} \mathrm{C}\right]$ & DBT $\left[{ }^{\circ} \mathrm{C}\right]$ & Altitude [m] \\
\hline \multirow{3}{*}{ Curitiba } & 0.4 & 30.9 & 23.2 & \multirow{3}{*}{908} \\
\hline & 1.0 & 29.8 & 22.6 & \\
\hline & 2.0 & 28.7 & 22.0 & \\
\hline \multirow{3}{*}{ Londrina } & 0.4 & 25.3 & 33.9 & \multirow{3}{*}{570} \\
\hline & 1.0 & 24.7 & 32.8 & \\
\hline & 2.0 & 24.2 & 31.9 & \\
\hline \multirow{3}{*}{ Iguaçu Falls } & 0.4 & 26.1 & 35.1 & \multirow{3}{*}{243} \\
\hline & 1.0 & 25.6 & 34.1 & \\
\hline & 2.0 & 25.1 & 33.1 & \\
\hline
\end{tabular}

For comparison, a high density DC of $414.72 \mathrm{~m}^{2}$ as shown in Figure 5 was used with the heat dissipation equipment ( $347.3 \mathrm{~kW}$ of sensitive heat, that is, $0.84 \mathrm{~kW} / \mathrm{m}^{2}$ ) added to the internal thermal load of $48 \mathrm{~kW}$, composed of driving and lighting $(8 \mathrm{~kW})$, people and others (40 kW of Nobreak and others losses).

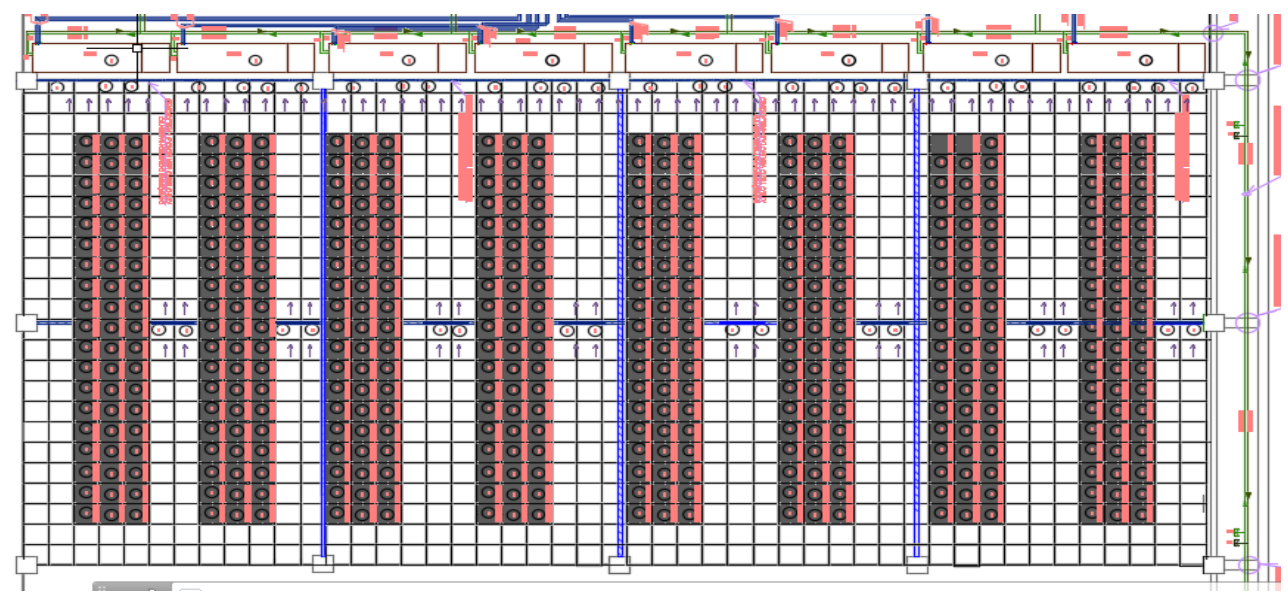

Figure 5. High density DC of $414.72 \mathrm{~m}^{2}$ used for calculations.

For this purpose, eight pieces of equipment (four effective and four reserve) with 30 Tons of Refrigeration (TR) "dual Fluid", with $85 \%$ of the sensitive heat factor. A Ton of Refrigeration (TR) is a unit often used as a general term to indicate the capacity or size of a refrigeration plant. It is defined as the rate of heat transfer for freezing (or melting) of 1 ton $(2,000 \mathrm{lb} ; 907 \mathrm{~kg})$ of pure ice at $0{ }^{\circ} \mathrm{C}\left(32^{\circ} \mathrm{F}\right)$ in 24 hours. ASHRAE defines $1 \mathrm{TR}$ as equivalent to a refrigeration capacity of $3516.85 \mathrm{~W}$ or $3023.95 \mathrm{kcal} / \mathrm{h}$. The dual fluid equipment has the technical specifications shown in Table 2.

Table 2. Characteristics of dual fluid equipment [17].

\begin{tabular}{lcc}
\hline \multicolumn{1}{c}{ Model } & Unity & L99 Model - LIEBERT Dual Fluid Equipment \\
\hline Total Cooling Capacity & $\mathrm{kW}$ & 104.6 \\
\hline Sensitive Cooling Capacity & $\mathrm{kW}$ & 89.3 \\
\hline Sensible Heat Rate & $\%$ & 85 \\
\hline COP & $\mathrm{kW} / \mathrm{kW}$ & 3.40 \\
\hline Number of compressors & $\mathrm{n}$ & 2 \\
\hline Air delivery & $\mathrm{m}^{3} / \mathrm{h}$ & 21100 \\
\hline
\end{tabular}


Table 2. Cont.

\begin{tabular}{lcc}
\hline \multicolumn{1}{c}{ Model } & Unity & L99 Model - LIEBERT Dual Fluid Equipment \\
\hline Max. Available Static Pressure & $\mathrm{Pa}$ & 90 \\
\hline Sound pressure level & $\mathrm{dB}(\mathrm{A})$ & 66.9 \\
\hline Width & $\mathrm{mm}$ & 2550 \\
\hline Depth & $\mathrm{mm}$ & 890 \\
\hline
\end{tabular}

For the approximate capacity of $30 \mathrm{TR}$ (Cooling ton of $104.6 \mathrm{~kW}$, for each of the eight pieces of equipment, four effective and four reserve), the nominal Energy Efficiency Rate (EER) is $3.4 \mathrm{~kW} / \mathrm{kW}$ (in the condition of direct expansion, considering a total nominal equipment consumption of $30.86 \mathrm{~kW}$, for the temperature condition of $35^{\circ} \mathrm{C}$ in the air intake of the condenser).

The energy efficiency data for DC air conditioning equipment are stipulated by AHRI 1361 (2017) [14]. Thus, the nominal air conditioning consumption to meet the aforementioned thermal load will be $123.44 \mathrm{~kW}$, of the four pieces of effective equipment. Therefore, the PUE will be:

$$
\begin{gathered}
\text { PUE }=\frac{\text { Total Energy (IT equipment }+ \text { air conditioning }+ \text { Lighting }+ \text { UPS losses and inverters and others })}{\text { Energy of IT equipment }} \\
\text { PUE }=\frac{(347.30+123.44+8+40)}{(347.3)}=1.50 \mathrm{~kW} / \mathrm{kW}
\end{gathered}
$$

A PUE of $1.50 \mathrm{~kW} / \mathrm{kW}$ is an excellent value. The performance of the air conditioning equipment was based on an inlet air temperature in the condenser of $35^{\circ} \mathrm{C}$. To establish a comparison, a simulation was performed using the CoolPack software [18] to determine the compressor's isentropic coefficient. For this purpose, the power of the evaporator and condenser fans were neglected. In other words, for an EER of $3.4 \mathrm{~kW} / \mathrm{kW}$ that includes the condenser and evaporator fans, the power of the fans $(7.36 \mathrm{~kW})$ was neglected, so the EER value $=104.6 \mathrm{~kW} / 23.5 \mathrm{~kW}$, will be $4.5 \mathrm{~kW} / \mathrm{kW}$ (compressor specific).

\section{Comparison of Indexes}

The PUE COA is the same PUE index, but with an emphasis on the energy of the Constant Outdoor Air. The outside temperature is on average $0.4 \%$ of the current highest temperatures of NBR 16401.

The EUED index $[10,11]$ works with $8760 \mathrm{~h}$ of data (use of energy instead of constant energy from outside air, which is already a suggestion for ISO 50006 [19] used as a buildings metric in $\mathrm{kWh} / \mathrm{m}^{2}$ ). Using the annual dry bulb temperature associated with the coincident dew point temperature (data from the ASHRAE Weather Data Viewer [15]), the EUED index is classified as:

- Free Cooling - a system that allows the use of the enthalpy characteristics of the outside air to acclimate rooms;

- Evaporative-direct or indirect adiabatic cooling, which consists of cooling the ambient air using the wet bulb temperature;

- A system for geothermal condensation (ground source) as a thermal bath option to condense the refrigerant fluid;

- $\mathrm{COP}-\mathrm{a}$ coefficient of performance, which is used to evaluate the relationship between the cooling capacities obtained and the work done to obtain it.

Based on an average air intake temperature of $20^{\circ} \mathrm{C}$, in the EUED methodology, the following systems were specified (using an altitude of $163 \mathrm{~m}$ corresponding to the average between the two cities in the study for an initial example, Iguaçu Falls and Manaus): 
A. Free Cooling is used when the outside air temperature is below $20^{\circ} \mathrm{C}$ and the enthalpy is below $42.797 \mathrm{~kJ} / \mathrm{kg}$.

B. An evaporative system is used when the temperature is between $15^{\circ} \mathrm{C}$ to $24^{\circ} \mathrm{C}$ and the enthalpy from $42.7979 \mathrm{~kJ} / \mathrm{kg}$ to $55.8233 \mathrm{~kJ} / \mathrm{kg}$.

C. When the temperature is above $20^{\circ} \mathrm{C}$ and enthalpy is above $55.8233 \mathrm{~kJ} / \mathrm{kg}$, the normal system is used under the following conditions:

1. COP1: Air intake temperature between $24^{\circ} \mathrm{C}$ and $27^{\circ} \mathrm{C}$;

2. COP2: Air intake temperature between $27.1^{\circ} \mathrm{C}$ and $30^{\circ} \mathrm{C}$;

3. COP3: Air intake temperature between $30.1^{\circ} \mathrm{C}$ and $33^{\circ} \mathrm{C}$;

4. COP4: Air intake temperature above $33.1^{\circ} \mathrm{C}$;

5. GEO: if a geothermal temperature is available, it will be used to determine the COP, with a $4{ }^{\circ} \mathrm{C}$ differential of the geothermal temperature.

The CoolPack software [18] was used to simulate the conditions of COP1, COP2, COP3, and COP4. The simulation started by condition COP4 to simulate a standard isentropic coefficient to be able to identify the COP with the variation in condensation temperatures. The effect of the condensation temperature was considered, adding $11{ }^{\circ} \mathrm{C}$ to the average air inlet temperature for each situation with the conditions shown in Figure 6. The results obtained with the software are described below for the cases of COP4 to COP1 in decreasing order. For the geothermal water condensation system, the value of $6^{\circ} \mathrm{C}$ was added [11].

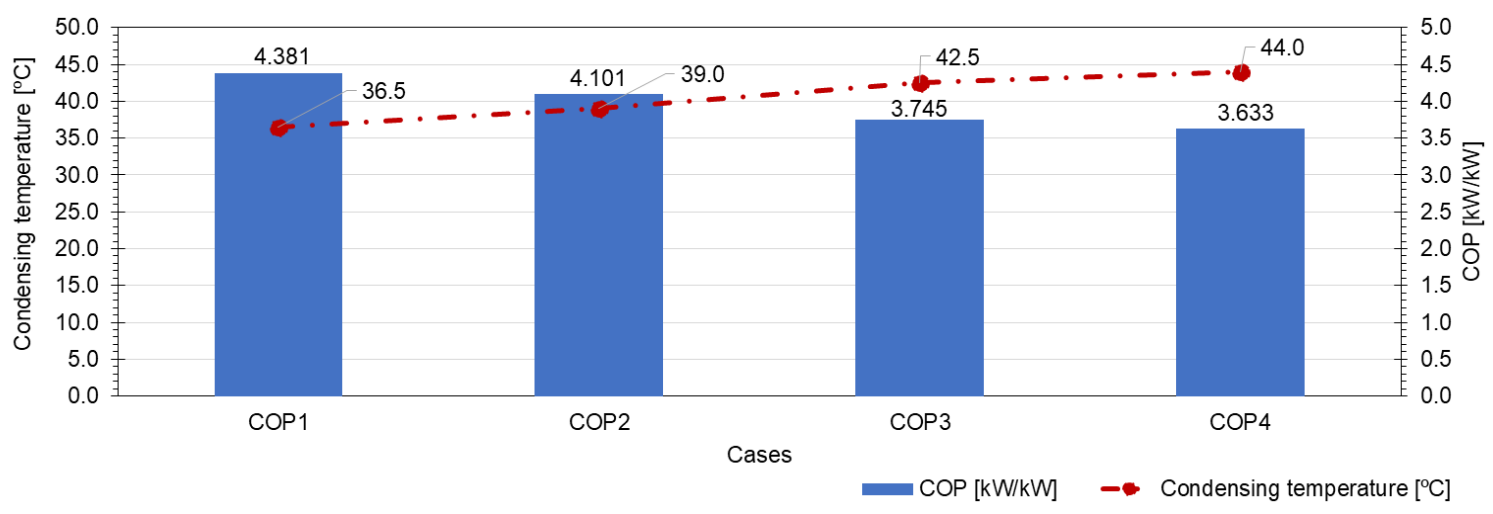

Figure 6. Condensing temperatures and coefficient of performance (COP) values for the different systems under simulation, for a refrigeration power $104.5 \mathrm{~kW}$, evaporation temperature of $5{ }^{\circ} \mathrm{C}$ and refrigerant R410A.

For each case study, COP is determined for two conditions, with or without the work of the fans. COP4 case study:

$$
\begin{gathered}
\mathrm{COP}_{\mathrm{wo} / \text { fans }}=\frac{\text { Refrigeration power }}{\text { compressors work }}=\frac{104.5}{21.64}=4.829 \mathrm{~kW} / \mathrm{kW} \\
\mathrm{COP}_{\mathrm{w} / \text { fans }}=\frac{\text { Refrigeration power }}{\text { (compressors + fans) work }}=\frac{104.5}{21.64+7.36}=3.633 \mathrm{~kW} / \mathrm{kW}
\end{gathered}
$$

COP3 case study:

$$
\begin{gathered}
\mathrm{COP}_{\mathrm{wo} / \text { fans }}=\frac{\text { Refrigeration power }}{\text { compressors work }}=\frac{104.5}{20.54}=5.087 \mathrm{~kW} / \mathrm{kW} \\
\mathrm{COP}_{\mathrm{w} / \text { fans }}=\frac{\text { Refrigeration power }}{\text { (compressors + fans) work }}=\frac{104.5}{20.54+7.36}=3.745 \mathrm{~kW} / \mathrm{kW}
\end{gathered}
$$


COP2 case study:

$$
\begin{gathered}
\mathrm{COP} 2_{\mathrm{wo} / \text { fans }}=\frac{\text { Refrigeration power }}{\text { compressors work }}=\frac{104.5}{18.12}=5.768 \mathrm{~kW} / \mathrm{kW} \\
\mathrm{COP} 2_{\mathrm{w} / \text { fans }}=\frac{\text { Refrigeration power }}{\text { (compressors + fans) work }}=\frac{104.5}{18.12+7.36}=4.101 \mathrm{~kW} / \mathrm{kW}
\end{gathered}
$$

COP1 case study:

$$
\begin{gathered}
\mathrm{COP}_{\mathrm{wo} / \text { fans }}=\frac{\text { Refrigeration power }}{\text { compressors work }}=\frac{104.5}{16.49}=6.338 \mathrm{~kW} / \mathrm{kW} \\
\mathrm{COP}_{\mathrm{w} / \text { fans }}=\frac{\text { Refrigeration power }}{\text { (compressors + fans) work }}=\frac{104.5}{16.49+7.36}=4.381 \mathrm{~kW} / \mathrm{kW}
\end{gathered}
$$

From the COP values obtained by the CoolPack [18] software and the basic data of the enthalpy system methodology for DCs, a system of wide psychrometric coverage was elaborated for all possible external temperature points, whether for "Free Cooling", Evaporative or just Cooling. Using the ASHRAE Climate Data Viewer [15], the association of dry bulb temperature frequencies with the dew point coincident temperatures was defined as the method. At each point, the enthalpies associated with this relationship were found in the following cumulative frequencies for each system and city as shown in Figure 7.

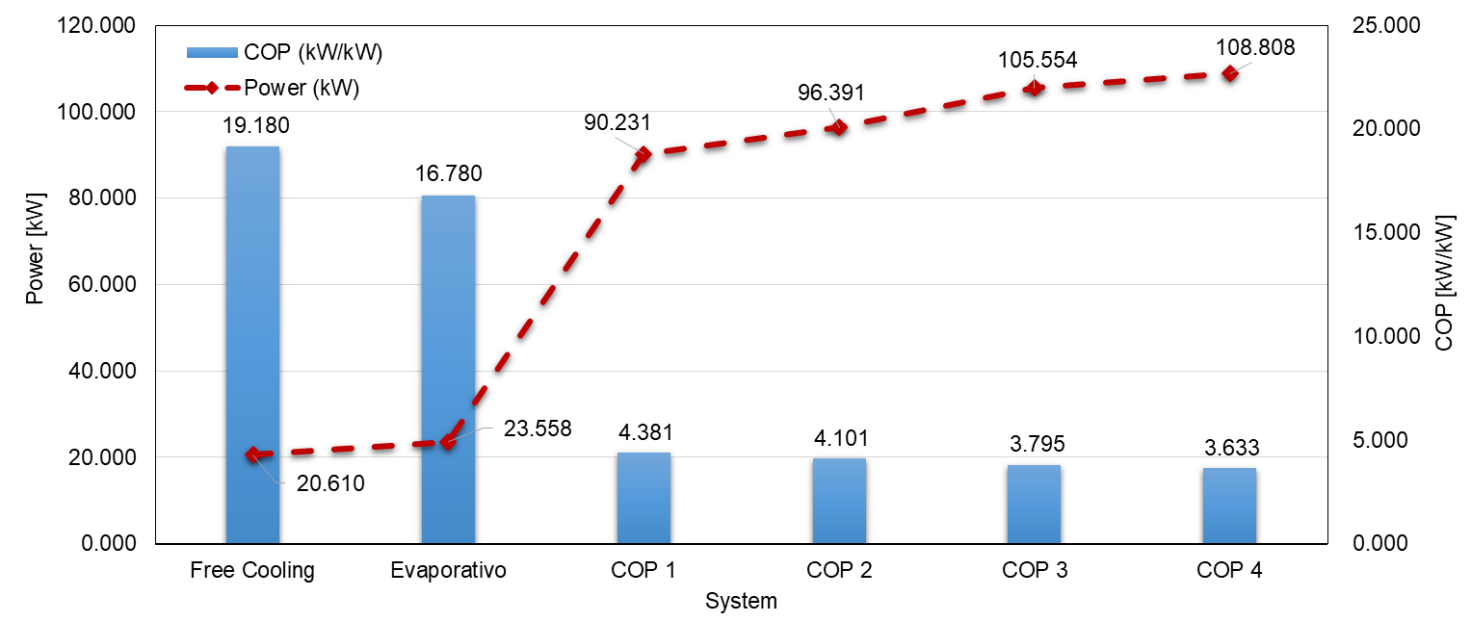

Figure 7. Data for psychrometric chart, with a total load of $395.3 \mathrm{~kW}$.

Using the same software ASHRAE [15], selecting the proposed EUED index, it classified the frequencies in hours of work for the three cities. It is worth mentioning that there are differences between cities. In Curitiba, using the evaporative system, when the temperature is between $15{ }^{\circ} \mathrm{C}$ and $24{ }^{\circ} \mathrm{C}$ and enthalpy between $42.7979 \mathrm{~kJ} / \mathrm{kg}$ and $55.8233 \mathrm{~kJ} / \mathrm{kg}$, there is higher frequency, which is $3453.887 \mathrm{~h}$; in Londrina there are $2054.839 \mathrm{~h}$ and Iguaçu Falls $2851.659 \mathrm{~h}$ of frequencies. With a Free Cooling system, with a temperature below $20^{\circ} \mathrm{C}$ and an enthalpy below $42.7979 \mathrm{~kJ} / \mathrm{kg}$, Curitiba has $4410 \mathrm{~h}$ of frequency, Londrina $1631.256 \mathrm{~h}$ and Iguaçu Falls $2069.853 \mathrm{~h}$.

Six levels were classified using the rules proposed in the EUED as shown in Figure 7: Free Cooling; Evaporative; COP1; COP2; COP3; and COP4. The cities of Curitiba, Londrin, a and Iguaçu Falls have different air consumption energies according to their temperature and enthalpy. In a period of $8760 \mathrm{~h}$, Londrina used $80.78 \%$ more energy than Curitiba, and Iguaçu Falls $84.77 \%$ more energy than Curitiba. Table 3 shows the relationship between COP and energy. The higher the COP, the lower the energy consumption. Table 4 gathers the final results in calculations using EUED index rules for the three possible locations for DC installation. 
Table 3. Calculations using Energy Usage Effectiveness Design (EUED) index rules.

\begin{tabular}{|c|c|c|c|c|c|c|}
\hline System & $\begin{array}{l}\text { Thermal } \\
\text { Load }[\mathbf{k W}]\end{array}$ & $\begin{array}{c}\mathrm{COP} \\
{[\mathrm{kW} / \mathrm{kW}]}\end{array}$ & $\begin{array}{c}\text { Power } \\
{[\mathrm{kW}]}\end{array}$ & $\begin{array}{l}\mathbf{h}_{\text {Curitiba }} \\
\text { [Hours] }\end{array}$ & $\begin{array}{l}\mathbf{h}_{\text {Londrina }} \\
\text { [Hours] }\end{array}$ & $\begin{array}{c}\mathbf{h}_{\text {Iguaçu Falls }} \\
\text { [Hours] }\end{array}$ \\
\hline Free Cooling & 395.3 & 19.180 & 20.610 & 4410.000 & 1631.256 & 2069.853 \\
\hline Evaporative & 395.3 & 16.780 & 23.558 & 3453.887 & 2054.839 & 2851.659 \\
\hline COP1 & 395.3 & 4.381 & 90.231 & 579.743 & 2813.931 & 2327.090 \\
\hline COP2 & 395.3 & 4.101 & 96.391 & 269.874 & 898.518 & 842.435 \\
\hline COP3 & 395.3 & 3.745 & 105.554 & 45.987 & 328.573 & 529.063 \\
\hline COP4 & 395.3 & 3.633 & 108.808 & 0.509 & 42.773 & 139.902 \\
\hline System & $\begin{array}{c}\text { Energybrk } \\
\text { Londrina } \\
\text { [kWh/year] }\end{array}$ & $\begin{array}{c}\text { Energy } \\
\text { Curitiba } \\
\text { [kWh/year] }\end{array}$ & $\begin{array}{c}\text { Energy } \\
\text { Iguaçu Falls } \\
\text { [kWh/year] }\end{array}$ & $\begin{array}{l}\text { Equipment } \\
\text { [kWh/year] }\end{array}$ & $\begin{array}{c}\text { Lighting } \\
\text { [kWh/year] }\end{array}$ & $\begin{array}{c}\text { Others } \\
\text { [kWh/year] }\end{array}$ \\
\hline Free Cooling & $33,620.212$ & $90,890.143$ & $42,659.685$ & $3,042,348$ & 70,080 & 420,480 \\
\hline Evaporative & $48,407.506$ & $81,366.013$ & $67,178.828$ & & & \\
\hline COP1 & $253,902.521$ & $52,310.503$ & $209,974.558$ & & & \\
\hline COP2 & $86,609.158$ & $26,013.493$ & $81,203.225$ & & & \\
\hline COP3 & $34,682.198$ & 4854.091 & $55,844.702$ & & & \\
\hline COP4 & 4654.099 & 55.362 & $15,222.442$ & & & \\
\hline Total air spend & $461,875.695$ & $255,489.606$ & $472,083.440$ & & & \\
\hline
\end{tabular}

Table 4. Final results in calculations using EUED index rules.

\begin{tabular}{cccc}
\hline City & Energy $[\mathbf{k W h} / \mathbf{y r}]$ & EUED [kWh/yr]/[kWh/yr] & EUED - PUE COA [\%] \\
\hline Curitiba & $3,788,397.606$ & 1.245 & $16.87 \%$ \\
Londrina & $3,994,783.695$ & 1.313 & $13.33 \%$ \\
Iguaçu Falls & $4,004,991.440$ & 1.316 & $13.30 \%$ \\
\hline
\end{tabular}

Figure 8 shows the comparative information of COP PUE COA and COP EUED. It shows that the COP EUED for Curitiba is larger than for the other cities (Londrina and Iguaçu Falls). Thus, it is the best way to map the possibilities in the project phase and have satisfactory results in the installation of new DC facilities.

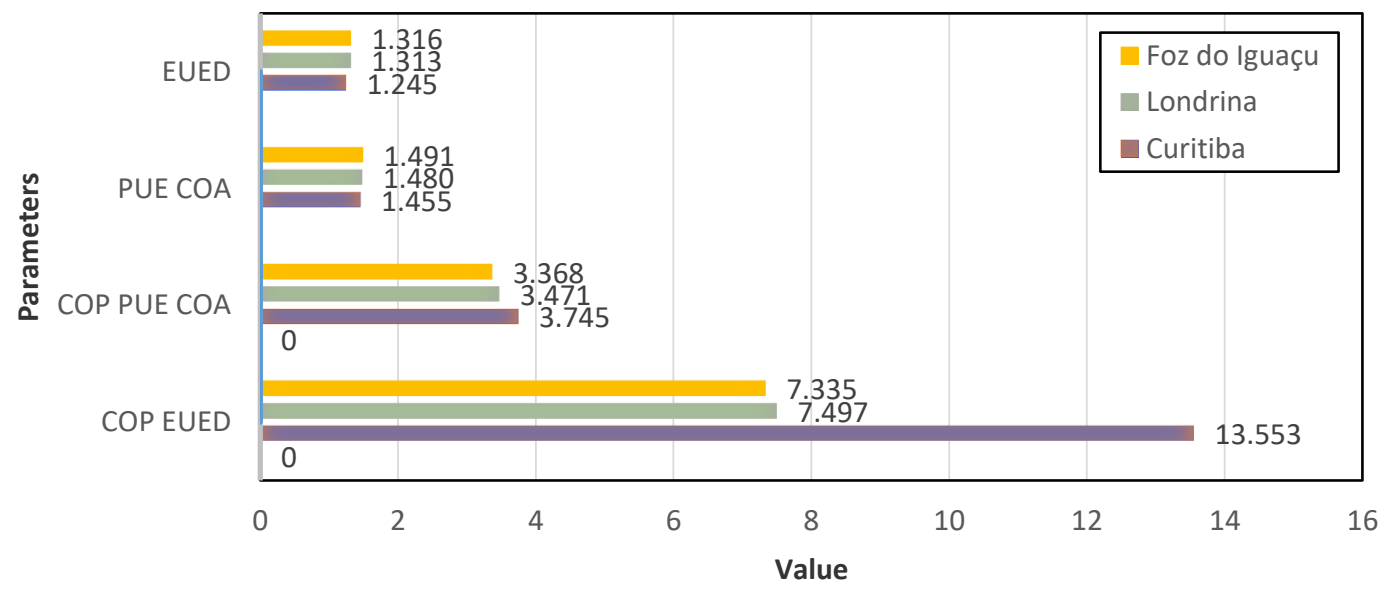

Figure 8. Comparison COP EUED, COP PUE constant external air temperature (COA), EUED and PUE COA.

\section{Using a New Index PDD (Perfect Design Data center) to Evaluate Energy Performance}

The PDD-Perfect Design Data center index is a redefinition of EUED given by Equation (1). It is an index that prioritizes efficiency in increasing order and that is easy to interpret since it varies 
between 0 and 1, 1 being a "perfect design". A decision abacus could be easily generated using the PDD that is given by Equations (12) and (13):

$$
\begin{gathered}
\text { PDD }=\frac{\text { annual } k W h \text { all DC with HVAC enthalp variations }}{\text { annual } k W h \text { IT equipment }]} \\
\text { PDD }=\frac{1}{\text { EUED }}
\end{gathered}
$$

Obtaining the PDD value, Pearson's linear correlation coefficient, $r$, can be determined, providing the strength of the linear correlation between two variables. Analyzing its result, it is possible to determine whether the use of the linear model as given by Equation (14) for modeling the phenomenon is appropriate [20].

$$
y=m \cdot x+b
$$

The angular, $m$, and linear, $b$, coefficients of Equation (14) must be determined by Equations (15) and (16) to develop the mathematical correlation.

$$
\begin{gathered}
m=\frac{(n \Sigma x y-\Sigma x \Sigma y)}{\left(n \Sigma x^{2}-(\Sigma x)^{2}\right)} \\
b=\frac{\left(\Sigma x^{2} \cdot \Sigma y-\Sigma x \cdot \Sigma x y\right)}{\left.\left(n \cdot \Sigma x^{2}\right)-(\Sigma x)^{2}\right)}
\end{gathered}
$$

The linear mathematical equation of PDD value in terms of COP EUED is given by Equation (17), as shown in Figure 9.

$$
\mathrm{PDD} \cong(76.171 \cdot \mathrm{EUED})-49.379
$$

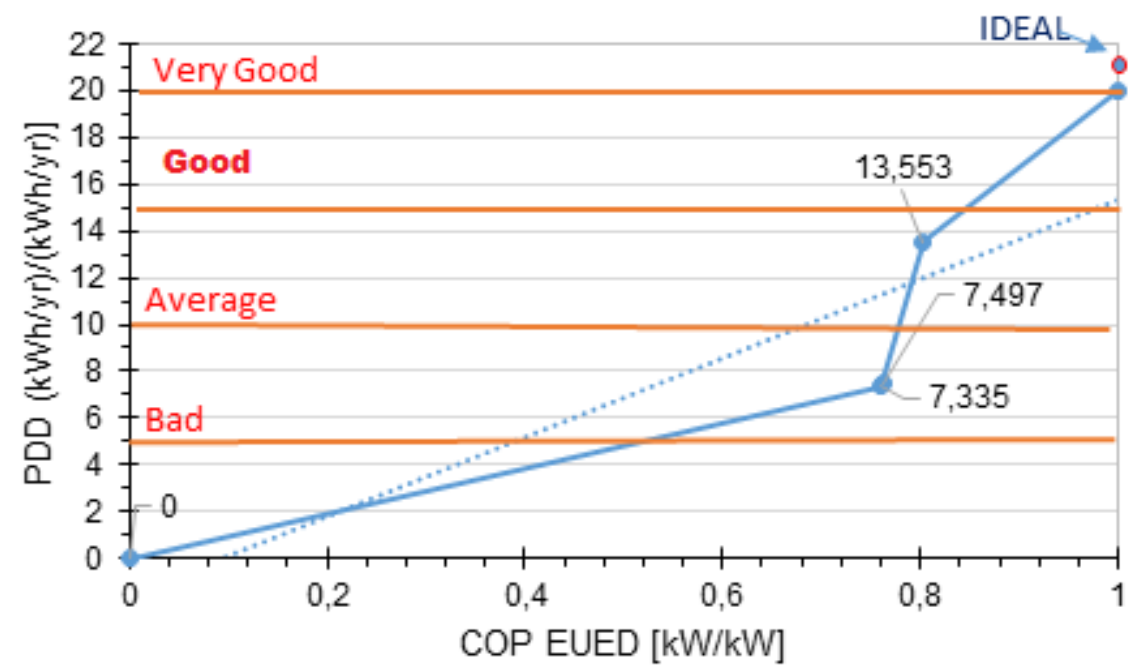

Figure 9. Linear correlation between the Perfect Design Data center (PDD) and COP EUED.

A ranking table was created for the PDD in relation to the COP EUED (Table 5):

Table 5. Classification for the construction of DC.

\begin{tabular}{ccc}
\hline Index & Condition for COP EUED & Classification for DC \\
\hline PDD & $>15.1$ to 20 & Very Good \\
PDD & $>10.1$ to 15 & Good \\
PDD & $>5$ to 10 & Average \\
PDD & 0 to 5 & Bad \\
\hline
\end{tabular}


Figure 10 shows the three cities surveyed in this study according to the PDD index classification, for the development of a DC construction project. Using this index, the best city to place a DC would be Curitiba with $0.803 \mathrm{~kW} / \mathrm{kW}$ of PDD (excellent classification).

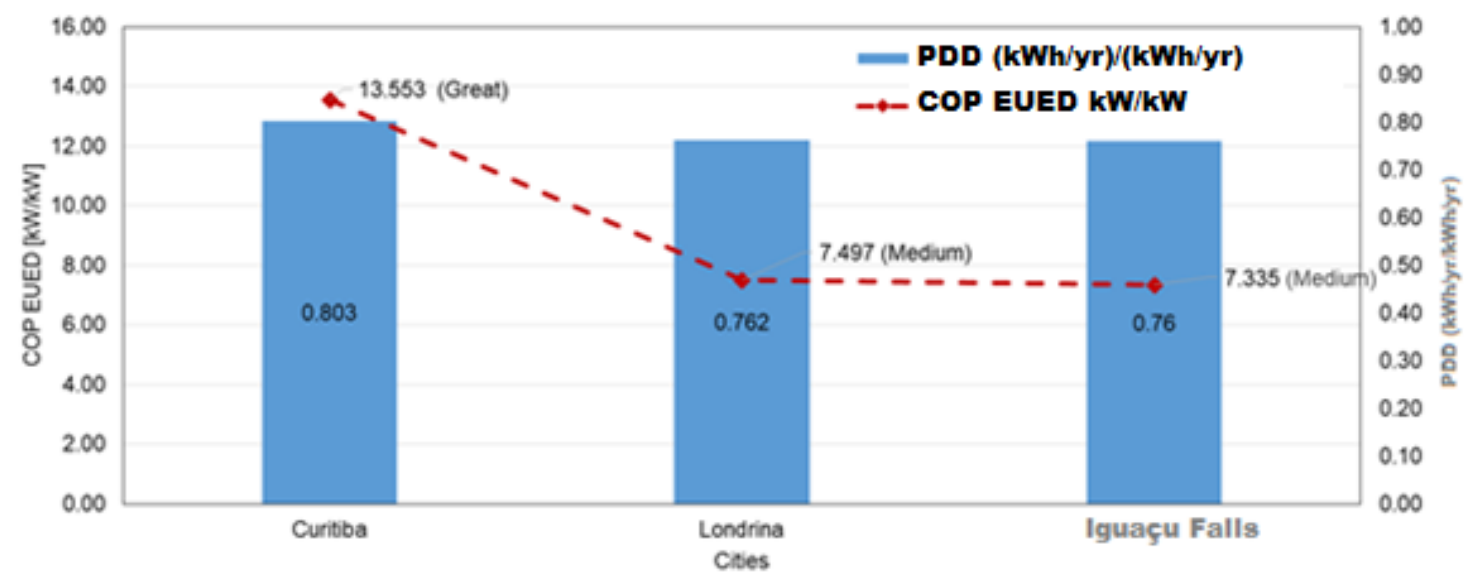

Figure 10. Comparison COP EUED vs. PDD.

\section{Conclusions}

The proposed EUED and PDD indexes are more reliable indices compared to the PUE COA, which is a metric that considers power in design. To analyze energy efficiency in new DCs, indexes were developed that use energy as a comparison element, making use of enthalpy utilization as a new methodology to obtain the results in the design phase (EUED). The PDD, a redefinition of EUED, is an index that prioritizes efficiency in increasing order and is easy to interpret. From a holistic point of view, enthalpy is an essential tool for choosing the best location to place a DC. Energy consumption of the infrastructure, which is the sum of energy consumption of air conditioning, equipment, lighting, and other equipment, between cities gives a difference of more than $5.45 \%$ in Londrina in relation to Curitiba and $5.72 \%$ from Iguaçu Falls in relation to Curitiba. The indexes obtained with the application of the EUED index were, respectively, $1.245(\mathrm{kWh} / \mathrm{yr}) /(\mathrm{kWh} / \mathrm{yr})$ for Curitiba, $1.313(\mathrm{kWh} / \mathrm{yr}) /(\mathrm{kWh} / \mathrm{yr})$ for Londrina and $1.316(\mathrm{kWh} / \mathrm{yr}) /(\mathrm{kWh} / \mathrm{yr})$ for Iguaçu Falls, showing a difference of $16.86 \%$ for Curitiba, Londrina $13.33 \%$ and $13.30 \%$ for Iguaçu Falls in relation to the PUE COA.

The PDDs of these cities were $0.803(\mathrm{kWh} / \mathrm{yr}) /(\mathrm{kWh} / \mathrm{yr})$ for Curitiba, $0.762(\mathrm{kWh} / \mathrm{yr}) /(\mathrm{kWh} / \mathrm{yr})$ for Londrina and $0.760(\mathrm{kWh} / \mathrm{yr}) /(\mathrm{kWh} / \mathrm{yr})$ for Iguaçu Falls. This index was created as a linear correlation $\mathrm{r}$ to be easily used as a decision-making tool for the location of a DC in the project phase.

The current method of AHRI 1361 [14] does not favor the varied COP, as in their conception it implies that due to the fixed thermal load of a DC there is no reason to measure efficiency in partial loads; this is a mistake because despite the fact that the thermal load is fixed, changes in the external temperature modify the compression ratios, favoring inverter and or digital scroll type equipment.

However, with the EUED index, there is an incentive for the DC Investor to use free cooling and an evaporative climatization system that can generate a lot of energy savings. In addition, the use of varied COP will favor digital or inverter type equipment that consumes less energy with the variation of air temperature intake in the condenser.

The emphasis used in this new method is for the installation of large DCs. While research [21] describes how layout changes and increased use of wireless transmission can minimize heat dissipation in DCs, the research described in this article shows how external enthalpic conditions can influence the decision of where to install it.

Author Contributions: Conceptualization, A.F.S. and P.D.G.; methodology, A.F.S.; validation, A.F.S. and H.J.L.d.S.; formal analysis, A.F.S. and P.D.G.; investigation, A.F.S.; resources, H.J.L.d.S.; data curation, A.F.S. and P.D.G.; writing—original draft preparation, A.F.S., H.J.L.d.S.; writing—review and editing, P.D.G.; visualization, H.J.L.d.S.; 
supervision, P.D.G.; project administration, A.F.S. All authors have read and agreed to the published version of the manuscript.

Funding: This research did not receive any specific subsidies from funding agencies in the public, commercial or non-profit sectors.

Conflicts of Interest: The authors declare no conflict of interest.

\section{Abbreviations}

$\begin{array}{ll}\text { ABNT } & \text { Association Brazilian Standards Techniques } \\ \text { ASHRAE } & \text { American Society of Heating, Refrigeration and Air Conditioning Engineers } \\ \text { COA } & \text { Constant Outdoor Air temperature } \\ \text { COP } & \text { Coefficient of performance } \\ \text { DC } & \text { Data Center } \\ \text { EER } & \text { Energy efficiency rate } \\ \text { EUED } & \text { Energy Usage Effectiveness Design } \\ \text { HVAC } & \text { Heating, Ventilating and Air Conditioning } \\ \text { IT } & \text { Information Technologies } \\ \text { ISO } & \text { International Organization for Standardization } \\ \text { NBR } & \text { Brazilian Standards } \\ \text { PDD } & \text { Perfect Design Data center } \\ \text { PUE } & \text { Power Usage Effectiveness } \\ \text { USA } & \text { United States of America } \\ \text { AHRI } & \text { Air-conditioning, Heating and Refrigeration Institute } \\ \text { IPLV } & \text { Integrated Part Load Value }\end{array}$

\section{References}

1. Furukawa Brasil. O Que Está Gerando o Crescimento dos Datacenters. Available online: https:/furukawabrasil.secure.force.com/pt-br/conexao-furukawa-detalhes/o-que-esta-gerando-ocrescimento-dos-data-centers (accessed on 14 April 2020).

2. Srgresearch. Hyperscale Data Center Count Jumps to 541 in Mid-2020, another 176 in the Pipeline. Synergy Research Group, Reno, USA. 2019. Available online: https://www.srgresearch.com/articles/hyperscale-datacenter-count-jumps-541-mark-us-still-accounts-40 (accessed on 17 September 2020).

3. 3M. Two-Phase Immersion Cooling: A Revolution in Data Center Efficiency; 3M: Saint Paul, MN, USA, 2015.

4. The Green Grid. PUE ${ }^{\mathrm{TM}}$ : A Comprehensive Examination of The Metric; Avelar, V., Azevedo, D., French, A., Eds.; White Paper \#49 Green Grid Association: Beaverton, OR, USA, October 2012. Available online: https://datacenters.lbl.gov/sites/all/files/WP49-PUE\%20A\%20Comprehensive\%20Examination\% 20of\%20the\%20Metric_v6.pdf (accessed on 14 April 2020).

5. Rasmussen, N. Implementing Energy Efficient Data Centers. White Paper Schneider Electric's Data Center Science Center; Schneider-Electric: Rueil-Malmaison, France, 2012.

6. Masanet, E.R.; Shehabi, A.; Smith, S.J.; Lei, N. Global Data Center Energy Use: Distribution, Composition, and Near-Term Outlook; Northwestern University: Evanston, IL, USA, 2018.

7. Cisco. Cisco Global Cloud Index: Forecast and Methodology, 2016-2021. 2018. Available online: https://www.cisco.com/c/en/us/solutions/collateral/service-provider/global-cloud-index-gci/whitepaper-c11-738085.pdf (accessed on 14 April 2020).

8. Shehabi, A.; Smith, S.; Sartor, D.; Brown, R.; Herrlin, M.; Kooney, J.; Masanet, E.; Horner, N.; Azevedo, I.; Lintner, W. United States Data Center Energy Usage Report LBNL-1005775; Ernest Orlando Lawrence Berkeley National Laboratory: Berkeley, CA, USA, 2016.

9. IEA. Tracking Buildings, Datacenters and Data Transmission Networks; International Energy Agency (IEA): Paris, France, 2019; Available online: https://www.iea.org/reports/tracking-buildings (accessed on 14 April 2020).

10. Santos, A.F.; Souza, H.J.L.; Cantão, M.P.; Gaspar, P.D. Analysis of Temperatures for Geothermal Heat Pumps Application in Paraná (Brazil). Open Engineering 2016, 6, 485-491. [CrossRef] 
11. Santos, A.F.; de Souza, H.J.L.; Gaspar, P.D. Evaluation of the Heat and Energy Performance of a Datacenter for a New Efficiency Index: Energy Usage Effectiveness Design-EUED. Braz. Arch. Biol. Technol. 2019, 62. [CrossRef]

12. AHRI_Standard_550-590. Performance Rating of Water-Chilling and Heat Pump Water-Heating Packages Using the Vapor Compression Cycle; Air-Conditioning Heating and Refrigeration Institute (AHRI): Arlington, TX, USA, 2015.

13. ASHRAE. Thermal Guidelines for Data Processing Environments. In ASHRAE Datacom Series: ASHRAE Technical Committee (TC) 9.9-Mission Critical Facilities, Technology Spaces, and Electronic Equipment, 3rd ed.; American Society of Heating, Refrigerating and Air-Conditioning Engineers. Inc: Atlanta, GA, USA, 2011.

14. AHRI Standard 1361 (SI). 2017 Standard for Performance Rating of Computer and Data Processing Room Air Conditioners; AHRI: Arlington, VA USA, 2017.

15. ASHRAE. ASHRAE Weather Data Viewer: WDVIEW; ASHRAE: Atlanta, GA, USA, 2017.

16. ABNT, 16401. Instalações de Ar Condicionado-Sistemas Centrais e Unitários, Qualidade do Ar Interior; ABNT: Rio de Janeiro, Brasil, 2008.

17. Emerson Network Power. Technical Specifications of Dual Fluid Equipment. Available online: http: //www.altayisisistem.com.tr/uploaded/_7329675555.pdf (accessed on 2 October 2020).

18. IPU. Coolpack - collection of simulation models for refrigeration systems. Available online: https://www.ipu. $\mathrm{dk} /$ products/coolpack/ (accessed on 2 October 2020).

19. ISO. ISO 50006:2014 Energy Management Systems-Measuring Energy Performance Using Energy Baselines (EnB) and Energy Performance Indicators (EnPI)_General Principles and Guidance; ISO: Geneva, Switzerland, 2014; p. 33.

20. Milone, G.; Angelini, F. Estatística Aplicada; Atlas: São Paulo, Brasil, 1995.

21. Shojafar, M.; Nicola, C.; Amendola, D.; Baccarelli, E. Energy Saving Adaptive Computing and Traffic Engineering for Real Time Service Data Centers. In Proceedings of the IEEE ICC 2015-Workshop on Cloud Computing Systems, Networks, and Applications (CCSNA), London, UK, 8-12 June 2015.

(C) 2020 by the authors. Licensee MDPI, Basel, Switzerland. This article is an open access article distributed under the terms and conditions of the Creative Commons Attribution (CC BY) license (http://creativecommons.org/licenses/by/4.0/). 